Research Article

\title{
Effective Communication and Conflict
}

\section{Management Workshop for Nursing Interns: Experience at a Tertiary Care Hospital of Delhi, India}

\author{
Alka Mishra', Deepak Bhardwaj', Jugal Kishore ${ }^{3}$ \\ ${ }^{1,2}$ Public Health Nursing officer, ${ }^{3}$ Director Professor \& Head, Dept. of Community Medicine, VMMC \& Safdarjung Hospital, New \\ Delhi, India. \\ DOI: https://doi.org/10.24321/2455.9199.202006
}

I $\quad \mathbf{N} \quad \mathbf{F} \quad \mathbf{O}$

Corresponding Author:

Alka Mishra, Dept. of Community Medicine, VMMC \& Safdarjung Hospital, New Delhi, India. E-mail Id:

alka1925@gmail.com

Orcid Id:

https://orcid.org/0000-0003-3195-1661

How to cite this article:

Mishra A, Bhardwaj D, Kishore J. Effective Communication and Conflict Management Workshop for Nursing Interns: Experience at a Tertiary Care Hospital of Delhi, India. Int J HealthCare Edu \& Med Inform 2020; 7(3\&4): 6-10.

Date of Submission: 2020-12-24

Date of Acceptance: 2021-02-09
$\begin{array}{llllllllllllll}\mathbf{A} & \mathbf{B} & \mathbf{S} & \mathbf{T} & \mathbf{R} & \mathbf{A} & \mathbf{C} & \mathbf{T}\end{array}$

Introduction: Communication is an important skill required in health care settings to deal with many problems including conflict management. Nurse serves patients in challenging environment with limited infrastructure, overcrowded wards and OPD, which poses the challenge of conflict and its management.

Method: Two workshops on the topic of communication and conflict management for nursing interns were conducted, these included various methods of teaching such as lecture and role-plays and interactive activities based on real-life situations. Data were collected on a pretested feedback forms and responses were obtained on 5-point Likert scale and also by open-ended questions.

Result: Majority of the nurse interns strongly agreed/ agreed that the topics were appropriate, increased their knowledge and they would recommend the workshop to their peers in future. They had learnt how to overcome barriers (93.61\%), professional communication (87.23\%), and good communication skills (72.34\%). Other take home messages, were, be a good listener, simple and precise message and empathy. They had also learnt various styles to solve conflict (95.48\%).

Conclusion: Student nurses were keen to learn about the effective communication and conflict management and were willing to implement learning at workplace.

Keywords: Communication, Resolving Conflict, Barriers

\section{Introduction}

Communication skill is one of the foremost important skills needed in health care settings. It helps in maintaining a professional as well as therapeutic nurse patient relationship better and it helps patients feel comfortable while they are sick and staying in hospital where all of their activities including activities of daily living are supervised by health personnel. Good communication makes patients 
feel by nurses' actions. Communication includes our voice modulation as we speak, the heed we pay to what the other person is trying to convey, the messages we give out includes all as by the way we move and position our bodies, eye contact, and the accuracy and clarity of what we communicate with person. ${ }^{1}$

The ability of the nurse to explain, listen, and empathize impacts relationships with patients and colleagues, which in turn can influence individual and organizational performance on clinical quality, experience of care, and financial consequences. ${ }^{2}$ Thus, it becomes important for institutions to invest more, in terms of time and resources to develop these skills in health care workers. Given the fact that nurses are in contact with patient and relatives for a significant period of time, it becomes essential for them to have good communication skills as it will help in enhancing patient experience, reduce complaints and increase nurse's self -confidence, professional standing, carrier prospects and job satisfaction and reduce stress. ${ }^{3}$

Incidence of workplace violence are increasing day by day in hospitals and community healthcare setting. A significant number of doctors had experienced violence in a tertiary care hospital of South Delhi, India. Verbal violence came out to be most common form of violence experienced by the health care teams. ${ }^{4}$ Afternoon or night hours were the timings when majority of such cases were reported. Nurses being vital part of health care delivery system cannot be spared from such act. According to WHO 8-38\% of health care worker suffer physical violence at some point in their career. ${ }^{5}$ In Delhi situation is not lagging too far. One in three health care staff at AlIMS faces violence. ${ }^{6}$ According to Indian Medical Association 75\% of doctors experience violence at work, while $80 \%$ of all assault on nurses go unreported. ${ }^{7}$

Nurses have inflexible working hours and more interactions with the patients and their relatives than any other member of health team. We cannot deny that nurse serves more patients in challenging environment where limited infrastructure, overcrowded wards and OPD, shortage of human resource are accepted as a norm. Nurses are expected to work at their optimum level. This leads to poor management of conflict with the members of health team such as physicians, colleague, and with the patient and their relatives. This may result in an argument, or assault Physical or verbal.

So, there is a need to address the conflict management. The department of Community Medicine is conducting workshop cum training on communication and conflict management to sensitize health care providers (doctors and nurses) with the aim of improving skills in communication and conflict management.

\section{Methods}

The workshop was organized to improve the awareness of nursing interns regarding effective communication and conflict management at workplace.

The Department of Community Medicine regularly organizes workshops on the topic of Communication \& Conflict Management for medical interns. Content of Communication and Conflict Management workshop was based on the workshop being implemented for undergraduate medical interns of the same institution on monthly basis. The content of this workshop was adapted according to the needs of nursing profession, with due permission from its organizers. ${ }^{8}$ Content of workshop was modified according to the need and settings of the nurses. Various role plays and activities for participants were designed in workshop which were based on real life experiences of work settings in hospitals. The modified workshop content was presented twice on different occasions before the faculty members and nursing and paramedical staff and their suggestions and feedback were incorporated. Two workshops on the topic of communication and conflict management for nursing students were conducted in the college of nursing attached to a tertiary care hospital in New Delhi.

The workshops were organized for B. Sc. Nursing interns who were in their 8th semester and were expected to complete $1056 \mathrm{hrs}$ of clinical experience within a duration of 22 weeks before appearing for their final examination. ${ }^{9}$ Workshop included various methods of teaching such as lecture and role-plays ensuring active participation of students using various interactive activities. These role-plays and activities were based on various real-life situations which nursing personal encounter at workplace. The participants were involved in interpretation of scenarios and their opinions about the same were sought.

Data was collected on a pretested feedback form which was also adapted from previous workshops. The first section of the feedback form was a 5-point Likert scale seeking opinion of participants, varying from strongly agree to strongly disagree, regarding appropriateness, need in profession, knowledge gain, plan to implement at workplace and possibility of recommending workshop to peers.

In the second section specific open-ended questions were asked about take-home message and plan for implementation at workplace. In the last section of the feedback form, participants were asked to give their comments on the workshop and suggestions for further improvement.

\section{The Topic of Communication was Covered Under Following Headings}

- $\quad$ Nurse patient relationships 
- Relationship \& communication

- Communication process

- Barriers to effective communication

- Effective communication model and

- Summary

\section{Conflict Management Was Covered Under Following Headings: What is Conflict}

- Epidemiological triad of conflict; Manifestation of conflict

- Response style; Methods of dealing with conflict; and After effect of conflict

The workshops were conducted on $11^{\text {th }}$ December 2019 and $18^{\text {th }}$ December 2019. A total of 47 nursing interns attended the workshops.

Results are expressed as frequencies and proportions. For overall workshop evaluation feedback, a rating of "agree" or "strongly agree" was considered to be an indicator of satisfaction with the workshop. The frequency with percentage were also calculated for open ended questions after coding and categorizing the responses.

\section{Result}

A total of 47 interns participated in the Communication \& Conflict Management Workshop. All the interns were females in the age group of 18 to 24 years.

Table I.Overall feedback for the workshop $(\mathbf{N}=47)$

\begin{tabular}{|c|c|c|c|}
\hline $\begin{array}{c}\text { Feedback } \\
\text { statement }\end{array}$ & $\begin{array}{c}\text { Strongly } \\
\text { Agree }\end{array}$ & Agree & $\begin{array}{c}\text { No } \\
\text { Comment }\end{array}$ \\
\hline $\begin{array}{c}\text { The topics were } \\
\text { appropriate for the } \\
\text { workshop }\end{array}$ & $\begin{array}{c}34 \\
(72.34 \%)\end{array}$ & $\begin{array}{c}13 \\
(27.66 \%)\end{array}$ & $0(0 \%)$ \\
\hline $\begin{array}{c}\text { I will recommend } \\
\text { this workshop to my } \\
\text { peers in future }\end{array}$ & $\begin{array}{c}33 \\
(70.21 \%)\end{array}$ & $\begin{array}{c}12 \\
(25.5 \%)\end{array}$ & $2(4.25 \%)$ \\
\hline $\begin{array}{c}\text { I think this } \\
\text { workshop is needed } \\
\text { in my profession }\end{array}$ & $\begin{array}{c}35 \\
(72.34 \%)\end{array}$ & $\begin{array}{c}12 \\
(27.66 \%)\end{array}$ & $0(0 \%)$ \\
\hline $\begin{array}{c}\text { This workshop } \\
\text { increased my } \\
\text { knowledge }\end{array}$ & $\begin{array}{c}36 \\
(76.59 \%)\end{array}$ & $\begin{array}{c}10 \\
(21.27 \%)\end{array}$ & $1(2.12 \%)$ \\
\hline $\begin{array}{c}\text { I plan to implement } \\
\text { the skills I learnt } \\
\text { today at this } \\
\text { workshop }\end{array}$ & $\begin{array}{c}34 \\
(72.34 \%)\end{array}$ & $\begin{array}{c}(27.66 \%) \\
13\end{array}$ & $0(0 \%)$ \\
\hline
\end{tabular}

Table 1, describes overall feedback of the nursing interns for the workshop. Majority of the participants strongly agreed/ agreed that the topics were appropriate, and they would recommend the workshop to their peers in future. More than $90 \%$ of the participants also strongly agreed that the workshop increased their knowledge, and that they would implement the skills they learnt from the workshop at their workplace.

Table 2.Feedback regarding take home messages reported by workshop participants (Multiple Responses Present) $(\mathbf{N}=47)$

\begin{tabular}{|c|c|c|c|}
\hline Section & $\begin{array}{c}\text { Take home } \\
\text { message }\end{array}$ & Frequency & Percentage \\
\hline \multirow{6}{*}{$\begin{array}{l}\text { Effective } \\
\text { commu- } \\
\text { nication }\end{array}$} & $\begin{array}{c}\text { How to Overcome } \\
\text { barriers }\end{array}$ & 44 & 93.61 \\
\hline & $\begin{array}{l}\text { Professional in } \\
\text { communication }\end{array}$ & 41 & 87.23 \\
\hline & $\begin{array}{c}\text { Good } \\
\text { communication } \\
\text { skills }\end{array}$ & 34 & 72.34 \\
\hline & $\begin{array}{c}\text { Be a good } \\
\text { listener }\end{array}$ & 30 & 63.82 \\
\hline & $\begin{array}{c}\text { Simple and } \\
\text { precise message }\end{array}$ & 21 & 44.68 \\
\hline & $\begin{array}{c}\text { Be Empathetic \& } \\
\text { polite }\end{array}$ & 20 & 42.55 \\
\hline \multirow{5}{*}{$\begin{array}{l}\text { Conflict } \\
\text { manag- } \\
\text { ement }\end{array}$} & Change in self & 26 & 55.31 \\
\hline & $\begin{array}{c}\text { Patient friendly } \\
\text { attitude }\end{array}$ & 15 & 31.91 \\
\hline & $\begin{array}{c}\text { Conflict } \\
\text { management is } \\
\text { necessary }\end{array}$ & 25 & 53.19 \\
\hline & $\begin{array}{c}\text { Adopt response } \\
\text { style to solve } \\
\text { conflict }\end{array}$ & 43 & 95.48 \\
\hline & $\begin{array}{l}\text { Admitting own } \\
\text { mistakes (be your } \\
\text { own boss) }\end{array}$ & 06 & 18.76 \\
\hline
\end{tabular}

*Multiple Responses Present.

Table 2, describes the frequency and percentage distribution of various topics which were covered in workshop. For the topic of communication skills, the most frequently reported take-home messages were how to overcome barriers (93.61\%), professional in communication (87.23\%), good communication skills (72.34 \%). Other home messages, were, be a good listener (63.82\%), simple and precise message (44.68\%), be an empathetic and polite (42.55\%).

For conflict management session most frequently reported take home message was adopting various style to solve conflict $(95.48 \%)$ followed by change in self $(55.31 \%)$ and conflict management is necessary (53.19\%). Other take home messages were patient friendly attitude (31.91\%) and admitting own mistakes (18.76\%). 
Table 3.Responses regarding plan to implement learning from workshop at workplace reported by workshop participants

\begin{tabular}{|c|c|c|c|}
\hline \multirow{2}{*}{ Topic } & Plan to implement at workplace & $\mathbf{N}$ & $\mathbf{\%}$ \\
\hline \multirow{4}{*}{ Effective communication } & Admitting own mistakes (be your own boss) & 45 & 95.74 \\
\cline { 2 - 4 } & Empathy & 29 & 61.70 \\
\cline { 2 - 4 } & Remove barriers & 26 & 55.31 \\
\cline { 2 - 4 } & Avoid Bias & 18 & 38.29 \\
\hline \multirow{3}{*}{ Conflict management } & Empathy & 08 & 18.60 \\
\cline { 2 - 4 } & Manage conflict & 20 & 42.55 \\
\cline { 2 - 4 } & Give quality care & 12 & 25.33 \\
\cline { 2 - 4 } & Avoid prejudice & 03 & 6.83 \\
\hline
\end{tabular}

*Multiple Responses Present.

Table 3, describes responses regarding the plan of implementing the new learnings at workplace. For the topic of communication skills majority of the participants (95.74\%) reported plan to implement good communication skills at workplace followed by empathy (61.70\%), removing communication barriers (55.31\%) and avoid bias (38.29\%).

For conflict management session, the most frequently reported plan of application at workplace was to manage conflict $(42.55 \%)$ and giving more time to patient as part of quality care (25.33\%).

The participants were asked to list down their suggestions for overall improvement of the workshop. A majority of the participants suggested that same workshop should also be "conducted for doctors and other staff of hospital," followed by suggestions to "include more activities and audio-visual content" while reducing lecture part in workshops. Some participants were of the opinion that the workshop should be more "intensive" rather than "extensive." Few participants suggested that the duration of workshop should be less to sustain the interest and focus of participants, as both communication skills and conflict management sessions were carried out consecutively.

\section{Discussion}

The workshop conducted on the topic of Communication and Conflict Management was successful considering the response received from the participants. A study conducted on medical students found that about $88 \%$ of the study participants were convinced about importance of learning communication for better practice and avoiding conflict at workplace. Participants of our workshop also reported similar opinions and acknowledged the importance of communication skills and various methods of conflict resolution as also suggested by other studies on medical and nursing personnel around the world. ${ }^{10-14}$

Inclusion of various roleplays and interactive activities in the Communication and Conflict Management workshop, which were based on real life situations faced by nurses every day in work settings, were also an important factor in making learning about communication and conflict management easy and interesting for students. Same has also been reported by other researchers about roleplays and activities. ${ }^{15-17}$

Though nursing education curriculum includes the topic of communication, but it may not be sufficient to develop communication skills and conflict management skills, which needs periodical reinforcement of the knowledge for implementation at workplace and in real life settings.

Overall feedback of nursing interns regarding Communication and Conflict Management Workshop encouraged us to expand our activity and include nursing and paramedical staff for training of communication skills and conflict management. If a sufficient number of healthcare workforce including nurses and paramedical staff are trained about communication skills and conflict resolution, we may be able to reduce the incidences of workplace violence and abuse.

Since the number of participants were very less the findings cannot be generalised, also as it was a one-day workshop without follow-up activities we were unable to determine the implementation of learning at workplace. In absence of repeated reinforcements behaviour change is hard to acquire.

\section{Conclusion}

Evaluation of communication skills and conflict management workshop showed that student nurses were keen to learn about the effective communication and conflict management. Majority of them found it useful and relevant to their work, also they expressed desire to implement the key learning point from workshop at workplace. Therefore, more such workshop should be organized regularly in other group of staff. 


\section{Acknowledgement}

Dr. Geeta Pardeshi, Dr. Shveta Lukhmana, Dr. Surabhi Sethi, Dr. Priyanka Sharma, Dr. Akanksha Bharti for sharing the content and guiding. All faculty members, residents, staff of Dept. of Community Medicine VMMC \& Safdarjung Hospital for their inputs in improving the content of the workshop. Principal College of Nursing VMMC \& SJH for Organizing workshop.

\section{Conflict of Interest: None}

\section{References}

1. Why communication is important | First Steps [Internet]. Rcni.com. [cited 7 Nov 2019]. Available from: https://rcni.com/hosted-content/rcn/first-steps/ why-communication-important

2. Communication: A Critical Healthcare Competency Patient Safety \& Quality Healthcare [Internet]. Patient Safety \& Quality Healthcare. 2020 [cited 8 December 2019]. Available from: https://www.psqh.com/analysis/ communication-critical-healthcare-competency

3. Contributor N. Benefits of Effective Communication in Nursing | Communication Skills 1 | Nursing Times [Internet]. Nursing Times. 2020 [cited 10 November 2019]. Available from: https://www.nursingtimes.net/ clinical-archive/assessment-skills/communicationskills-1-benefits-of-effective-communication-forpatients-20-11-2017/

4. Violence against health workers [Internet]. World Health Organization. 2020 [cited 7 Nov 2019]. Available from: https://www.who.int/violence_injury_prevention/ violence/workplace/en/

5. Kumar M, Verma M, Das T et al. A Study of Workplace Violence Experienced by Doctors and Associated Risk Factors in a Tertiary Care Hospital of South Delhi, India. J Clin Diagn Res 2016; 10(11): LC06-LC10. Published online 2016 Nov 1. doi: 10.7860/JCDR/2016/22306.8895 PMCID: PMC5198359

6. Workplace Violence in Healthcare [Internet]. Nagalandpost.com. 2020 [cited 12 Dec 2019]. Available from: https://www.nagalandpost.com/workplaceviolence-in-healthcare/200267.html

7. News C, News D. One in three healthcare staff at AlIMS faces violence | Delhi News - Times of India [Internet]. The Times of India. 2020 [cited 12 Dec 2019]. Available from: https://timesofindia.indiatimes. com/city/delhi/1-in-3-healthcare-staff-at-aiims-facesviolence/articleshow/69779390.cms

8. Sethi S, Pardeshi G, Kishore J. Communication Skills for Interns: Evolution and Assessment of a Training Workshop in a Medical College of New Delhi. Int J HealthCare Edu \& Med Inform 2019; 6(2): 17-22.

9. [Internet]. Indiannursingcouncil.org. 2020 [12 Dec 2019]. Available from: http://www.indiannursingcouncil.org/
pdf/BSCSyllabus_2019-20.pdf

10. Choudhary A, Gupta V. Teaching communications skills to medical students: Introducing the fine art of medical practice. Int J App Basic Med Res 2015;5, Suppl S1:41-4P.

11. Kaur H, Kaur S, Kapoor R. A Study to Assess the Relationship between Perceived Quality of Therapeutic Communication and Nursing Care Satisfaction among Patients. International Journal of Nursing Care 2015; 3:1: 23-26P. Print ISSN: 2320-8643. Online ISSN: 23208651. DOI: 10.5958/2320-8651.2015.00006.X

12. Kumari A, Kaur T, Ranjan P et al. Workplace violence against doctors: Characteristics, risk factors, and mitigation strategies: J Postgrad Med 2020; 66(3): 149154. Published online 2020 Jul 14. doi: 10.4103/jpgm. JPGM_96_20 PMCID: PMC7542052,PMID: 32675451

13. Madhivanan A, Vinayagamoorthy $V$, Dongre AR. Physical Violence Against Doctors: A Content Analysis from Online Indian Newspapers. Indian JCommunity Med 2020; 45(1): 108-109. DOI: 10.4103/ijcm.IJCM 215_19,PMCID: PMC6985956 PMID: 32029997

14. Abd-Elrhaman ESA, Ghoneimy AGH. The Effect of Conflict Management Program on Quality of Patient Care. American Journal of Nursing Science 2018; 7(5): 192-201. DOI: 10.11648/j.ajns.20180705.

15. Rosengren K, Lepp M, Widyawati. Drama, Leadership and Conflict Management to Support Nurse's Professional Development - A Qualitative Study in Indonesia. International Archives of Nursing and Health Care DOI: 10.23937/2469-5823/1510135.

16. Nair BT. Role play - An effective tool to teach communication skills in pediatrics to medical undergraduates. J Educ Health Promot 2019; 8: 18. DOI: 10.4103/jehp.jehp_162_18.

17. Kahkoska AR, DeSelm TM, Young LA. Assessment of third-year medical students' comfort and preparedness for navigating challenging clinical scenarios with patients, peers, and supervisors. BMC Med Educ 2020; 20(1): 71. Published 2020 Mar 12. DOI:10.1186/s12909020-1984-1. 